\title{
AJANTA CAVES: A PERSPECTIVE ON CONSTRUCTION METHODS AND TECHNIQUES
}

\author{
Akanksha Agrawal ${ }^{1}$, P.Megha Naidu ${ }^{2}$, Ravindra Patnayaka ${ }^{3}$ \\ ${ }^{1} 4$ th year student, B.Arch, School of Architecture, GITAM University, Visakhapatnam, Andhra Pradesh, India \\ ${ }^{2} 4$ th year student, B.Arch, School of Architecture, GITAM University, Visakhapatnam, Andhra Pradesh, India \\ ${ }^{3}$ Assistant Professor, School of Architecture, GITAM University, Visakhapatnam, Andhra Pradesh, India
}

\begin{abstract}
Ajanta Caves, UNESCO World Heritage Centre in India had its historic glory dating back to $2^{\text {nd }}$ Century $B C$ to $6^{\text {th }}$ Century $A D$ has become an outstanding exemplary for Ancient Rock Cut Architecture in India. The series of Buddhist caves comprising Chaityas (Commemorative Prayer Halls) and Viharas (Private Prayer Halls with resting cells) onto the horse shoe cliff away from the chaos, amidst nature must have assured the serenity in environment and tranquility for the inhabitants then. Ajanta, exhibits its efficiency in terms of various construction methods and techniques adopted for manifestation by the then artisan, as well as richness in terms of awe inspiring ornamentation both in paintings and reliefs where in majority of the interpretations in accordance to Gandhara Art. This paper focuses mainly on discussing various construction techniques and methods adopted for extrusion of form, purpose of various spatial fragments within vicinity and reflectance of various functional attributes of potential building elements that reinforced sustainability of the vicinity both structurally and aesthetically with the support of visual analysis. Also, other essential strategies such as ornamentation throwing light on Buddhist theology and water management to ascertain the comfort factor for the then inhabitants. This paper concludes with the appraisal of the rock cut mechanisms, design strategies and approaches while promoting a scope for further research in bringing out the practical applications as well issues regarding ambient indoor lighting and ventilation. Also with an anticipation of exploring the then safety concerns along with management strategies for serene and isolated living. Ajanta with its physical setting and articulation of various functional spaces as a sustainable habitat for centuries together does have heritage footprint with an exuberant research quotient.
\end{abstract}

Keywords: Ajanta Caves, Buddhist, Rock Cut Architecture, Construction Techniques, Gandhara Art. $* * *$

\section{INTRODUCTION}

Indian rock cut architecture is found in abundance than any other type of rock cut architecture in any other part of the world. It is the process of creating a structure by carving it out of a rock. Indian rock cut architecture is mostly religious in nature. There are more than 1500 known rock cut structures in India varying from caves to temples and even mere shelter forms. The Indian rock cut marvels date back to the reign of Pallavas. Monolithic rock cut architecture of Kailashnath temple at Ellora and Panchrathas are among the best examples of rock cut temples. (fig 1a [1] \& 1b [2]) Even the sculptures were not kept apart from this rock cut style, the Gomateshwara statue in Shravanabelagola, Karnataka is known to be the largest monolithic statue in the whole world(fig. 1c) [3] The influence of this style is found the best in Buddhist caves, containing prayer halls, private cells etc. Caves both natural and manmade have always been the special architectural attraction. The result is such that, the religious sanctuaries even today, are cave like structures. The caves have always stood as calm and sacred places, away from the chaos of life. This type of art form is more sculptural than architectural; hence the final product has to be kept in mind, before the work has even started. [4]

Even though rock cutting started as early as $200 \mathrm{BC}$, it reached its zenith only in $600 \mathrm{AD}$ during the reign of Pallavas .The conventional methods used have been chisel and hammer when it comes to rock cut style. The whole procedure takes place in phases- holes are made in the stone, which then house the wooden wedges that are hammered. Hot water is poured into the holes. The wooden wedge starts expanding. When a series of holes are made in the rock, it breaks down into two pieces (fig. 1e [5]) In case of a monolithic structure, the rock is not broken but every single detail is carved out of the same rock. The stones are shaped properly, also called dressing; and then they are engraved, if needed. Reverse mapping is another method used especially in rock cut architecture. This method has been extensively used in India, in the caves of Ajanta and Ellora(fig 1d [6]) The name itself explains, that the complete chiseling process takes place, from top to bottom, with predetermined plot, followed by detailing once the initial form is carved as seen in Kailasanath temple (fig. 1a) 

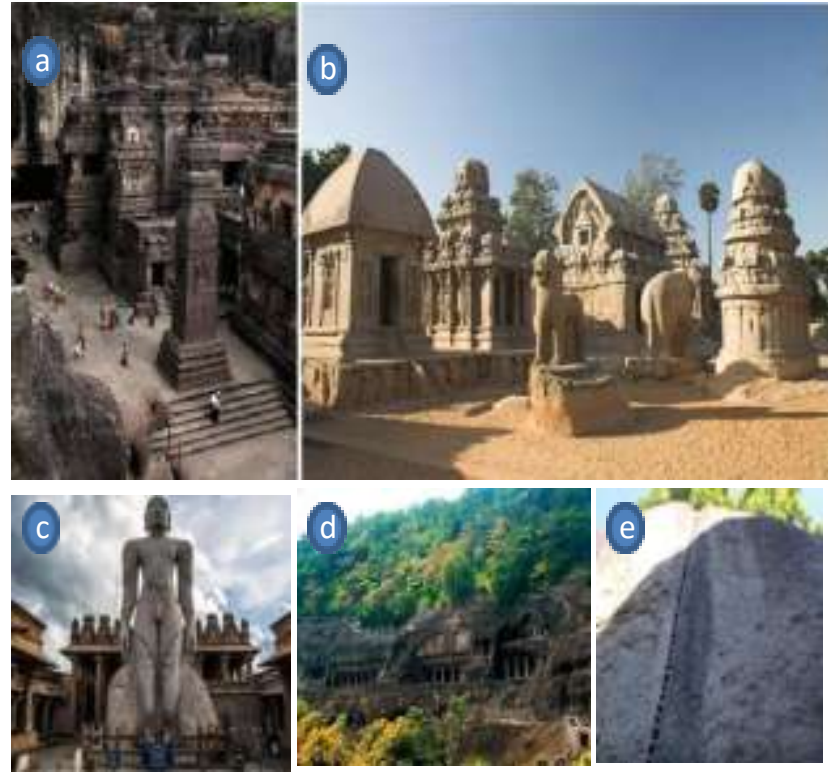

Fig 1: Rock cut Architecture

The intricate design of Ajanta, detailed carvings on the walls, different typologies of pillars and grand entrances as well as fresco type paintings, etc are of prime interest and attract people to explore more. The caves have acted as resting places for the monks, that were calm and away from chaotic surroundings that helped them meditate. The Hinayana monks needed a private space for meditation, as their sole aim was the attainment of nirvana (fig.1d) [6]. On the other hand, the Mahayana sect believed in helping others attain nirvana first, by preaching the teachings of Buddha. They needed larger spaces for the same with Commemorative spaces had either the belongings, or the statues related to the preaching of Buddha.

\section{PHYSICAL SETTING OF AJANTA CAVES}

Located 107 Kilometres North of Aurangabad, Maharashtra, India Ajanta caves is a UNESCO World heritage site. It got its name from the village Ajanta which is located just outside the caves. Standing at an altitude of 586 metres above sea level, $20.55^{\circ} \mathrm{N} \& 75.70^{\circ} \mathrm{E}$, they are a series of 29 rock cut Buddhist Chaityas which are the prayer halls and Viharas which are the hall of residences. The maximum and minimum temperature during summer and winter are 20 to $40^{\circ} \mathrm{C}$ and 10 to $30^{\circ} \mathrm{C}$ respectively.[7](fig. 2a [8])

Ajanta caves are constructed in two periods, first belonging to the 2 nd century BCE to 1 st century $\mathrm{CE}$, and second period that followed several centuries later. The earliest caves consist of 9,10,12,13, and $15 \mathrm{~A}$, constructed during the Hinayana period under the patronage of Satavahana dynasty during $100 \mathrm{BC}$ to $100 \mathrm{CE}$. The second phase of construction began in the 5th century. It is predicted by the experts that work took place during the reign of Harisena of Vakataka dynasty[9]. It is also said that the statues were added 600 years later after the caves were constructed.
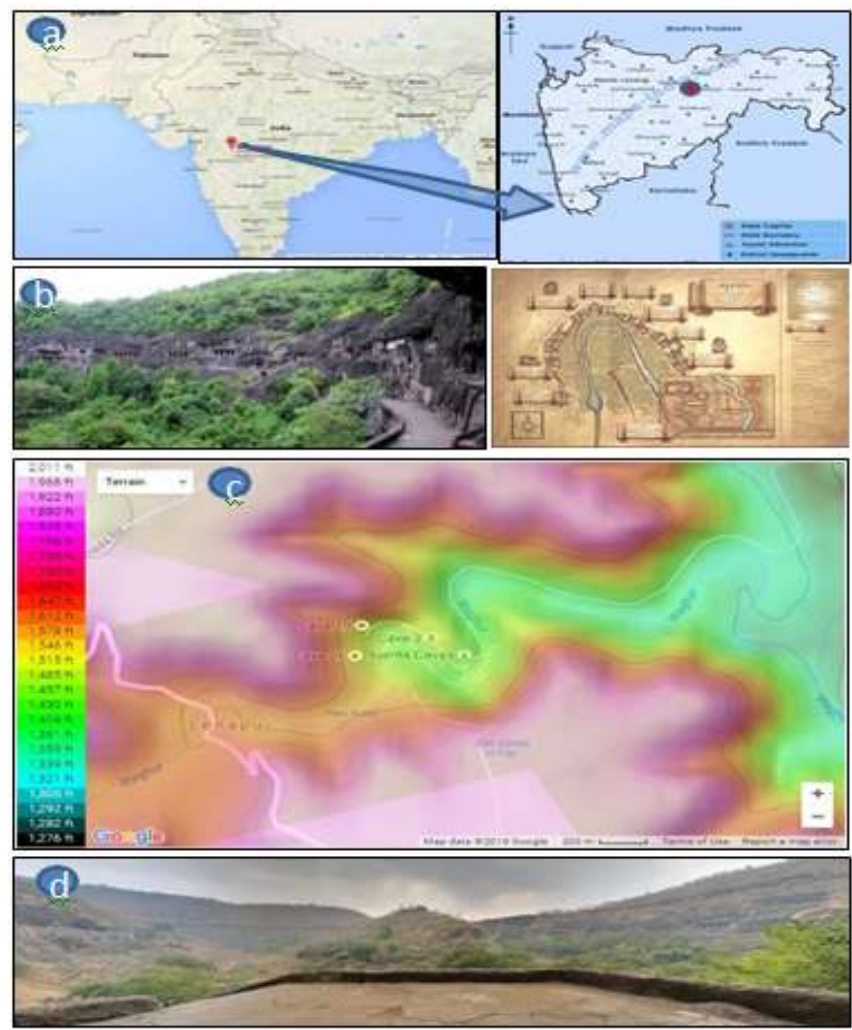

Fig 2: Physical Setting

The caves are surrounded by thick forests which enhance the overall beauty of the site and make it calm and pleasant. Because of the dense forests the caves remained undiscovered until 1819. The natural beauty of the area makes it clear why the monks chose the site for their spiritual purpose

Built in basalt stone of Western Ghats, the caves are excavated out of a horseshoe shaped cliff along with Waghora river which streamed directly to caves(fig 2b [10]) This could also be a reason for choosing the site as there was ample water and forests resources available. With undulations in the topography of the site, the caves vary from 10 metres to 33.5 metres in elevation above the river. [11](fig 2c [12])Each cave was connected to the stream by a flight of steps, which are now almost obliterated; traces of some could be noticed at some places. [13] Because of the form of the cliff, all the caves have a panoramic view of the river and mountain ranges.(fig $2 \mathrm{~d}$ ) Out of the 29 caves, cave number 9, 10, 19,26 and 29 are Chaityagrihas and the rest are Viharas. Chaityas were used to worship Lord Buddha while the Viharas were used by the Buddhist monks for resting, residing and meditation. The monks also carried out their studies in these monasteries. The caves also contain sculptures and paintings depicting Buddhist art and lifestyle.

Excavation of basalt rocks could have possibly been done from the top downward and inward (Reverse mapping) without the use of scaffolding. Holes could have cut into the cliff with chisel and hammer where windows were intended, then narrow passages and ceilings carved, after which alleys widened into corridors leading into halls and chambers divided by columns [14]. 
Basalt is a common extrusive igneous rock that has been used in architecture for centuries [15]. It is a porous material with naturally occurring holes. They tend to have the consistent coloration, marking and subtlety of a limestone. Its appearance is dull and soft; the color varies from black, brown, light to dark grey. It is largely composed of minerals with little resistance to weathering. It is also resistant to heat, pressure and water. It is difficult to carve basalt because of its hardness. The presence of chlorophate in basalt rock has the tendency to absorb moisture [16].

\subsection{Chaityas}

The facade of Chaitya has a prominent entrance with arched window to light the interior, also relief sculptures added in Mahayana period. The interior consists of a long vaulted nave with pillared aisle on either side. The far end is semicircular apse consisting of a stupa at its centre. The aisle also had access surrounding the stupa with carvings representing the pradakshina patha in temple architecture.

The earliest Chaitya is the cave 10. It imitates the then vernacular wooden construction to the extent that the rafters and beams are also sculpted even though they are non functional.

\subsection{Viharas}

The viharas have square or rectangular plan form with a congregation hall and cells for the monks on the inner sides. They also contain pillared aisle and nave along all the four sides. The maximum height is about 15.8 metres. (fig 2c) The design of the Viharas is varied with some being simple and the others ornamented with carvings and paintings on walls, ceilings including the facade. The Viharas were not intended to have shrines as they were meant to be used solely as halls of residence but later having a shrine at the back of the wall became a norm.

\section{CONSTRUCTION TECHNIQUES}

AND

\section{BUILDING ELEMENTS}

\subsection{Rock Cut Technique}

Excavation of the basaltic mountain could have been done by cutting a tunnel section on the roof level, which later got continued downwards. After the basic vertical profile was achieved, the further inwards scooping in could have been adopted, as observed in cave 24(fig 3a).

The rock out of which the sculpture or the structure has to be made could have been divided into rectangles that are carved on the rock according to the measurements. The rectangles form a grid, based on which the shape and design of the structure is decided. The rectangles are kept or chiseled out depending on the outline and shape of the structure (fig 3b\& c [5])

The form of the caves could have been achieved with such precision and refinement, by the process of scooping into the rock. The sequential procedure could have resulted in the appropriate design of the caves we see today. On the other hand, if we pay attention to the reliefs, and sculptures present in the caves, it can be said that they were scooped out and chiseled on the surfaced rock that was achieved after the excavation [5].
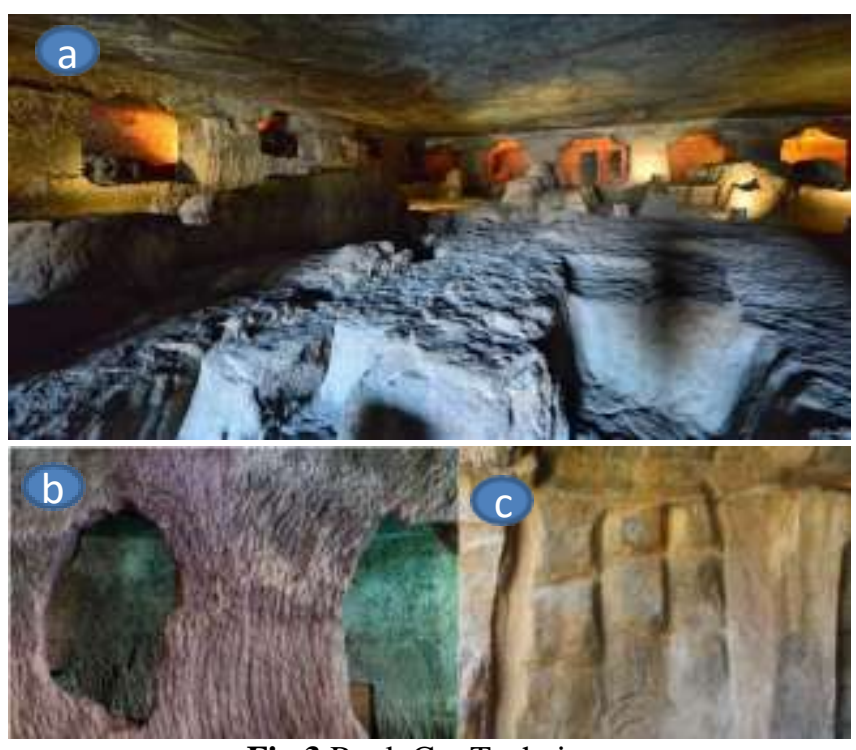

Fig 3 Rock Cut Technique

\subsection{Ceiling Typologies with respect to Functional}

\section{Spaces}

Ajanta caves comprise of a series of viharas and chaitya halls having differences in their respective ceilings observed as well. The viharas had private cells for the then monks, to reside and meditate inside. These cells were places surrounding the central common space which might have served as a place of congregation. These viharas, being the private spaces, did not require a lot of light. This could have been the reason behind the low height flat ceilings in the viharas. Since the spaces were private, they had to appear as if they were calm and secluded. (fig 4d) The less the presence of light, the more the space appears subtle. On the contrary, the chaitya halls had high vaulted ceilings, complimented by the sun windows at the entrances. (fig $4 \mathrm{e}$ ) These windows on one hand, enhanced the grandeur, and on the other hand, enabled the maximum penetration of light as well. Chaityas were mostly prayer halls that housed a larger number of people and were used to a maximum during the daytime. To add on to the serenity of the prayer hall, light was used as an aesthetic element. To achieve this, the ceiling height had to be more making sure that the light faces no obstruction. The main attraction of these prayer halls is the stupa placed at the apsidal end of the hall, which was intended to be focused and highlighted. Had it been a flat ceiling, the complete appearance would have been destroyed. The vaulted ceiling stands as a symbol of grandeur and helps makes the stupa focal element in the whole setting. It also lets the light from the sun window, easily access the stupa and illuminate it so well, that anybody gets overwhelmed inside. The vaulted ceiling along with the sun window function together to achieve the intention of highlighting stupa, and everything else in the 
cave stands as a backdrop thus making stupa a focal point (fig 4f). The ceiling being a functional element stands aesthetically pleasing as well. Beams and rafters are carved on the rock. This could have been done to imitate the ancient wooden construction and add an aesthetic quality. In viharas, the ratio of span to height is less than that in chaityas. The viharas have a larger span to accomodate private cells, whereas, the absence of these cells in chaityas result in a lesser span.

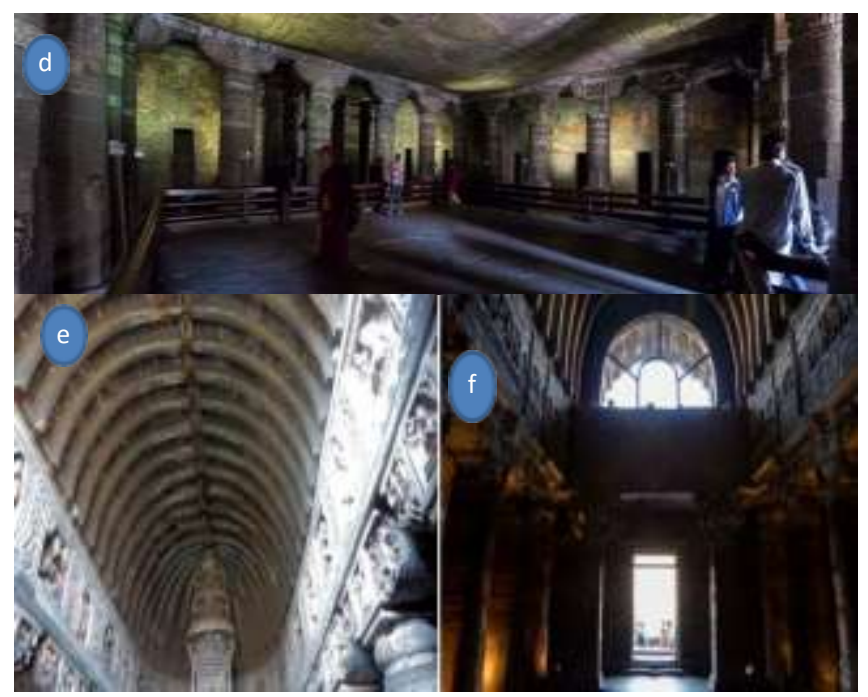

Fig 4 Ceiling Typology

\subsection{Ceiling Heights}

Most of the caves throughout the world have a high ceiling height. The reason is to allow proper ventilation. Higher ceiling height allows hot air mass to rise up and hence keeps it away from the normal height, allowing cool air to settle there. Since, cool air is denser, it gets settled there and keeps that part of the room volume cooler. But, most of the ceilings at Ajanta are low raised. There is a possibility that this was done experimentally to achieve the necessary ventilation required, but by using a different strategy. The low height could have been planned to allow the tunnel effect in a horizontal manner. Since the height of the ceiling was low, there was nowhere else for the hot air to go, possibly except the cells on the either ends which had cool water in them. That water could have cooled down the hot air in return. It can be said, that the principle of evaporative cooling could have been used, at that time, which now acts as a working principle for air conditioners. (fig 5)
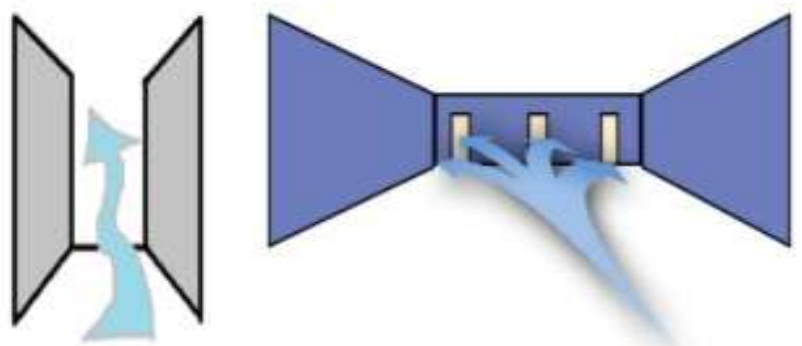

Fig 5 Illustration of Tunnel Effect inside the Cave

\subsection{Typology of Pillars}

The typical Buddhist columns are of two types Persepolitian and Graeco-roman. Persepolitian type is an octagonal column with bell shaped capital supporting animal sculptures. The shaft is highly polished and has a vase shaped base. The Graeco-roman is rectangular, octagonal or circular with shallow flutes. They are tall and slender, with a height 6-8 times its lower diameter. At the top, is a capital usually with a fluted vase motif. Ajanta has both the typologies; some pillars are even combination of both. The Chaityas have very simple columns with minimum ornamentation. The columns are tall and slender so as to support the heavy vaulted ceiling above, whereas the viharas have a varied range of columns with varying slenderness ratios. For example caves 1, 2, 4, 17 etc have similar type of columns having octagonal shafts with medium thicknesses. (fig 6a)These caves are of similar sizes as well. The prototype for pillared porch at the entrance initiated at cave 2 (fig 6b). This indicates that cave 1 was among the earliest constructions. The placement of pillars and selection of slenderness ratios as well as the design seems to be an outcome of the various experiments and ideas. As one moves from the starting, the differences can be easily observed in the design. For example, if we consider caves 6 , 7 and cave 10 which were viharas and chaitya respectively, we can see the variation in the interior spaces. Caves 6 and 7 have an antechamber separated from the main common hall by a series of pillars before entering the individual cells. This partial separation is kept intact in cave 10, the only difference being that the columns are not arranged in the grid as in caves 6 and 7. (fig 6c [8]) Cave 10 has two rows of columns widely spaced from each other which help outline the path from entrance to the stupa, providing a perfect perspective.(fig 6d [8] \& e) There has been gradual development in the design of caves .The evidence can be seen in the caves from 1- 9. Cave 1 has just a periphery of columns, followed by some more caves. This was later modified in cave 6 , where a grid form was intended and the evidence is more number of columns symmetrically placed. Since, the number of columns increased, the slenderness also increased. The thickness of columns in the earlier caves is compensated in cave 6 by using more number of columns which are slender. By the time, it was cave 10's turn; there might have been an intention of creating a prayer hall. As cave 10 , is the first cave where the columns, demarcate the clear walkway that straight away leads to the stupa. 


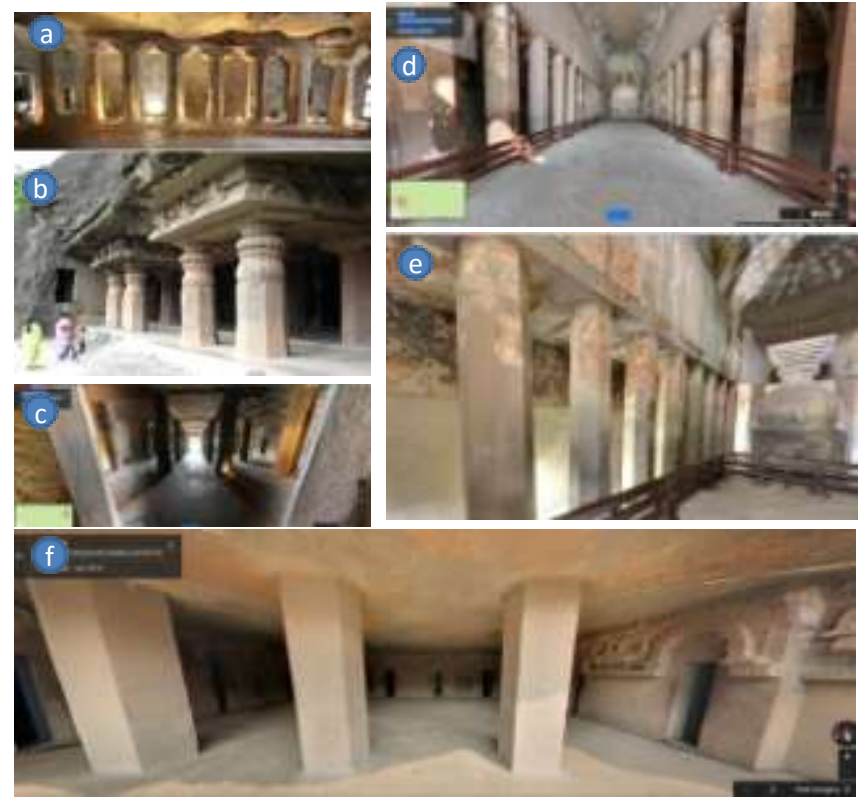

Fig 6 Pillar Typology

The design can be said to have started and developed gradually from cave to cave. Change of column placement and their slenderness depending on the size of the spaces can be seen. Initially they could have started from peripheral placement, followed by paired placement like in cave 2 , and then developed to a more organized grid pattern in caves 6 , 7. In caves 21 and 23, thicker columns are used with less spacing, since the space is smaller.

The trial and error method did not stop here. The caves 13 and 15 are without any columns whereas, cave 12 have columns only towards the entrance like the prostyle temples during the roman times. This also would have been done on a complete experimental basis, since the columns are not equally spaced, and each has a different thickness. (fig $6 f$ [8])

\subsection{Role Play of Sculpted Beams}

The role played by sculpted structural members in execution of a good design is not unknown. Beams are as important as any other member and are a part of the basic framework. The intriguing fact is the unknown reason for the presence and absence of beams in Ajanta. Not all caves have beams. The reasons are still unknown. There is only one way that the beams could have acted as a structural support system, and that is, if the rock at that particular portion has had cracks, resulting in the possibility of collapse or breakage. Then beams could have acted as a later addition by scooping in some more to prevent the further damage and support the cracks. (fig 7a)

Since the whole setting has been carved out of a single rock, no special structural supports other than the columns would have been needed. Despite this, most of the caves have beams. In cave 2 , there are shallow beams, whereas in some other caves, the depth has increased. The beams could have been a result of the intention to plan according to the grid. In caves like 6 and 7 where the columns were arranged in grid, the beams also follow the grid pattern, resembling present day drop slab construction. (fig 7b)

The presence of beams could have been an imitation of wooden beam construction like in cave 10 , since there was no additional structural support needed, or, it might have been done to create a visual frame which could emphasize the cells, that fell in exact centre and the statue as well. The upper and lower tie beams together with the left and right columns look like a framed photograph having the statue, only three-dimensional. (fig 7c)

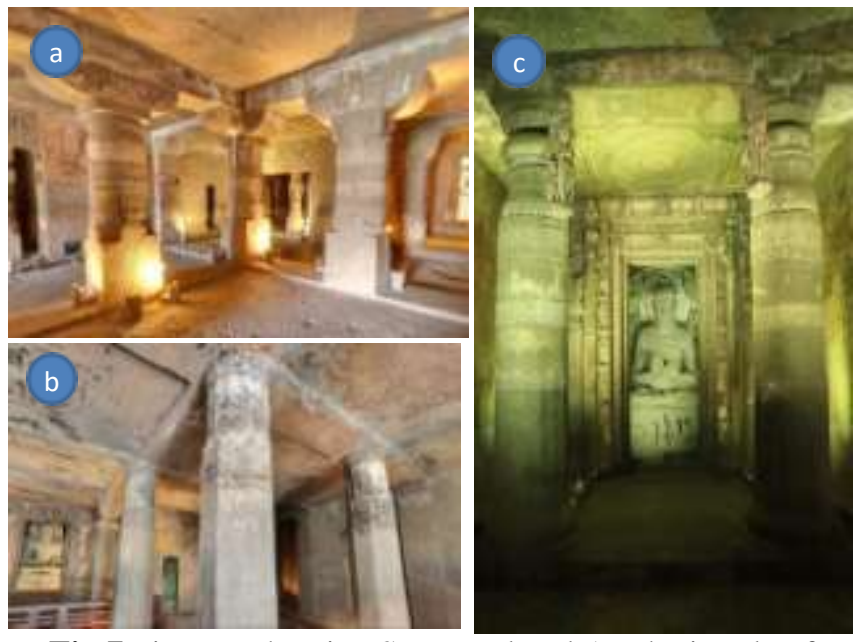

Fig 7 Pictures showing Structural and Aesthetic role of Beams

\section{INTERIOR DECORATION AND ORNAMENTATION: RELIEFS AND} PAINTINGS

As mentioned above, the monasteries were not only used for meditation and as a resting place, but also a place for the monks to study. The wall paintings, murals and reliefs provided a perfect platform to serve this purpose even today. The theme of the paintings is Gandhara art which represents the life of Buddha and Bodhisattvas and the Jataka stories. (fig 8a) They act as a continuous narration of all aspects of human life from birth to death depicting every kind of human emotion. The paintings also reflect the contemporary life of all times, dresses, ornaments, culture, weapons used, beliefs, gods and human beings. Devotees of Buddha during that time were supposed to walk through the cave and read the paintings which were used as a medium of communicating Buddha's teachings about 'life through successive rebirth'. Taking an example of cave number 26 as it is more elaborately and exquisitely provided with sculpted Figs, the various elements that represent Buddha's life are the horseshoe arch which shows fine sculptures of Buddha, the circumambulatory passage which represent the Sravasti miracle based on the legend when Buddha revealed himself in all his various forms on the skies above the village of Sravasti, a vital Buddha head with curly hair and large ear lobes, and a family group with floral decoration around it which shows the ideal human family of the time.[17](fig 8b, c \& d) 
The precision, perfection and harmony of the paintings done with only primitive tools make them world famous. The process was such that a layer of clay was mixed with cow dung and powdered rice hunk, also urine (suggested). This was first applied to the chiseled rock surface. After drying, second coat of lime plaster was applied with a trowel. The colors were made from pebbles and vegetables which were crushed and ground and then mixed with glue. The lines of the image were then drawn in pink, brown or black and the colors filled with big brushes made from hair of squirrel tails. These paintings cannot be called as frescos as fresco paintings do not use any binding agent, therefore they are known as murals. [18]

The existing condition of paintings is deteriorating. The paintings have been smoked and covered with dust, dirt and insect nests with flaking and peeling being common. Human vandalism like scratches causes a great deal of damage. The organic matter provides the insects a good breeding place. Bats and other creatures' excreta have disFigd the paintings. Since the paintings hold a heritage value, measures have been taken to conserve them. Some of which include spraying of insecticides and repellents, consolidation of weak and loose plaster, chemical treatment, application of preservative coat, etc. These processes are being carried out at an yearly basis.

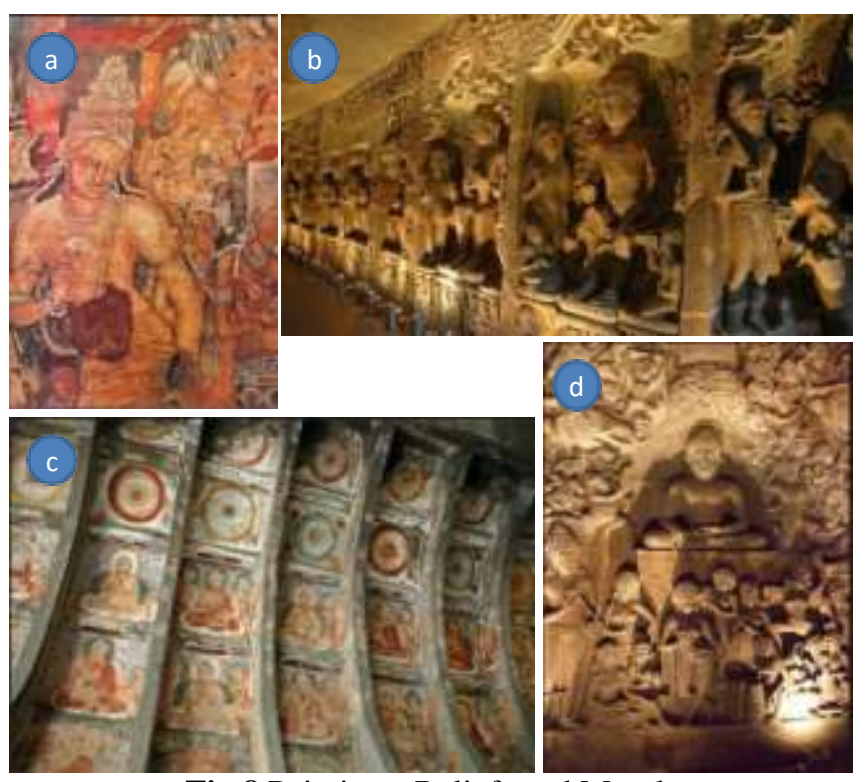

Fig 8 Paintings, Reliefs and Murals

\section{WATER MANAGEMENT}

It is believed that caves of Ajanta had cisterns for the storage of water. In some of the caves, the viharas on either side of the central hall are slightly elevated. They could have accommodated cisterns in side. The cisterns could have stored the water, as well as acted as a refrigerant to cool down the hot air. Since there is no evidence of wells, in the caves, cisterns could have been the only source of water, which could have been stored in them during the rainy season. (fig 9a) There are channeled sections cut into the rock, which could have helped carry the water into the cisterns.(fig 9b \& c) Waghora river would have served as the major water source. There might have been a water bearing zone near the river, which could yield a good quantity of water, to be used in summer months, if the river went dry. [19]

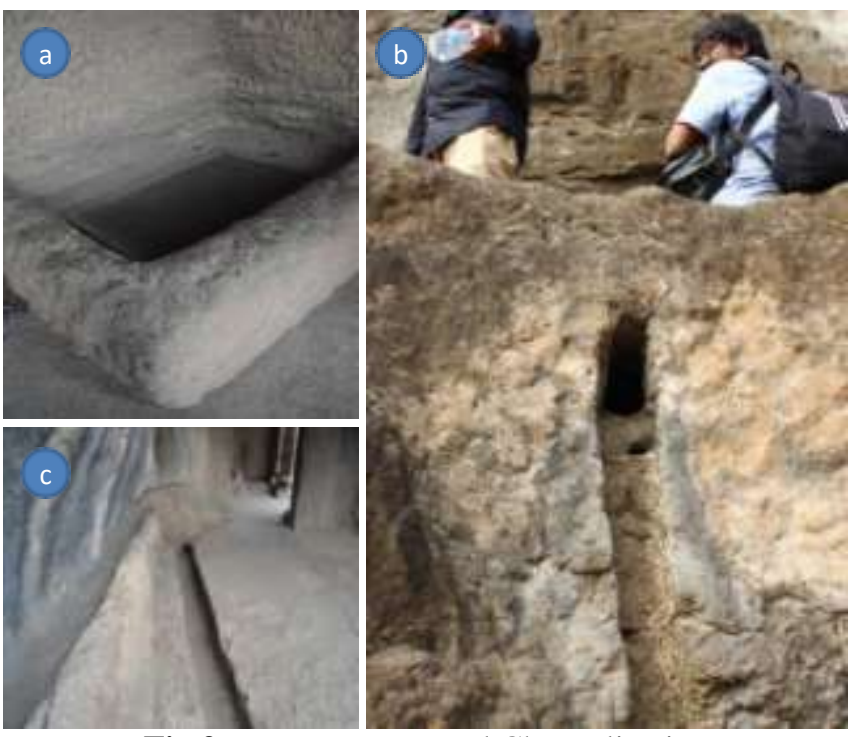

Fig 9: Water storage and Channelization

\section{CONCLUSION}

The caves of Ajanta date back to some thousands of years. This did not keep the people away from thinking and experimenting on some of the recent contemporaries. The efficiency with which the various design ideas got converted into reality is probably not possible, even today, though equipped with the best techniques and modernistic approaches. Achieving such precision with rock cut structures is an architectural miracle in itself. The intricacy of the carvings and the sensuous representations of glamorous princes, princesses, animals, silks, jewellery in all its mortal richness are a joyous vision of natural lifestyle and divine beauty. Aesthetics along with functionalism was achieved equally well. The caves served as a resting place for the monks but the functional mechanisms behind lighting and ventilation are still to be explored. The caves were mainly used by the monks, who occupied them during monsoon, as it was their resting period making it the most populous time of the year. Further research has to be done, so as to, conclude how far did these external factors favoured the survival, and if they did, how was it achieved. Ajanta, though witnessed by so many researchers and experts who have dedicated their life to it, still is not completely known by anyone of them. There are still so many hidden facts that are unexplored yet, making Ajanta a constant area of interest in everybody's mind

\section{REFERENCES}

[1]. Kailash temple,ellora caves. (n.d.). Retrieved september 26, 2016, from pinterest: https://www.google.co.in/search?hl=en\&site=imghp\&t $\mathrm{bm}=\mathrm{isch} \&$ source $=\mathrm{hp} \& \mathrm{biw}=1366 \& \mathrm{bih}=638 \& \mathrm{q}=$ ellora + caves +kailash+temple\&oq=ellora\&gs_l=img.1.3.0110.

3138.6208.0.7777.10.8.1.1.1.0.121.676.5j2.7.0...0...1a 
c.1.64.img..1.9.684...0i30k1j0i5i30k1.DYo5xcIKAFg\#

$\mathrm{hl}=\mathrm{en} \& \mathrm{t}$

[2]. Panchrathas Travel Info. (n.d.). Retrieved september 26, 2016, from Trawell: http://www.trawell.in/tamilnadu/mahabalipuram/panch arathas

[3]. Fernandez, R. (n.d.). Retrieved september 26, 2016, from flickr:

https://www.flickr.com/photos/7402324@N05/150295

41874

[4]. saraswati, a. (n.d.). rock cut temple architecture. Retrieved september 21, 2016, from www.speakingtree.in: http://www.speakingtree.in/blog/rock-cut-temple-

architecture

[5]. videos, P. t. (Director). (2014). Ancient Indian Rock Cutting Technology [Motion Picture].

[6]. Quick Guide Ajanta Ellora. (n.d.). Retrieved september 26, 2016, from Outlook Traveller : http://www.outlooktraveller.com/weekend- breaks/quickguide-ajanta-and-ellora-maharashtra- 1007711\#20609

[7]. Ajanta. (n.d.). Retrieved september 21, 2016, from goibibo: https://www.goibibo.com/travelguide/india/destination-ajanta/

[8]. ajanta caves. (n.d.). Retrieved september 26, 2016, from google

https://www.google.co.in/maps/place/Ajanta+Caves/@ maps:

$22.0229308,76.0743048,5.75 \mathrm{z} /$ data $=! 4 \mathrm{~m} 5 ! 3 \mathrm{~m} 4 ! 1 \mathrm{~s} 0 \times 3 \mathrm{~b}$

d97f7014a75e43:0x7ca8d7c57639691f!8m2!3d20.551

$8603 ! 4 \mathrm{~d} 75.7032521$ ?hl=en

[9]. Spink, W. M. (2005). arguments about Ajanta.

[10]. sightseeing. (n.d.). Retrieved september 26, 2016, from the meadows aurangabad: http://www.themeadowsresort.com/sightseeing3.htm\# [11]. contributors, N. W. (n.d.). Ajanta caves. Retrieved september 21, 2016, from newworldencyclopedia: http://www.newworldencyclopedia.org/entry/Ajanta_C aves [12]. ajanta caves. (n.d.). Retrieved september 26, 2016, from topographic map.com: http://en-in.topographicmap.com/places/Ajanta-Caves-4021940/

[13]. World Heritage Sites- Ajanta Caves. (n.d.). Retrieved september 21, 2016, from Archeological Survey of India: http://asi.nic.in/asi_monu_whs_ajanta.asp

[14]. Majewski, L. J. (1975-1976). Report on Examination of Murals of Ajanta Caves in India. Retrieved september 22, 2016, from JSTOR: https://www.jstor.org/stable/3179348?seq=1\#page_sca

n_tab_contents

[15]. Rangwala, S. (2013). Engineering Materials( material science). In S. Rangwala, Engineering Materials( material science) (p. 11). charotar publishing house pvt. ltd.

[16]. what is basalt. (n.d.). Retrieved september 22, 2016, from comparerocks: http://www.comparerocks.com/en/what-is- basalt/model-7999

[17]. ajanta caves. (2001-2015). Retrieved september 23, 2016, from the ancients: http://www.thelivingmoon.com/43ancients/02files/Indi a_Ajanta_Caves.html

[18]. Pisani, L. (2013, august 6). The Ajanta Cave Paintings. Retrieved september 23, 2016, from The Global Dispatches: http://www.theglobaldispatches.com/articles/the- ajanta- cave-paintings

[19]. Mr.Ranghunathan. (n.d.). geology. Retrieved 9 23, 2016, from maharashtra government website: https://cultural.maharashtra.gov.in/english/gazetteer/au rangabad/CHAP01/GEOLOGY.htm

\section{BIOGRAPHIES}

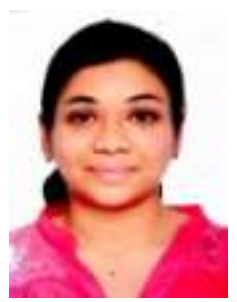

B.Arch., $4^{\text {th }}$ Year Student, enthusiastic in documentation, analysis and Research as a part of her interests along with the course curriculum in the fields of Design, History and Urban aspects.

Mobile: 09581510805 ranu6395@gmail.com

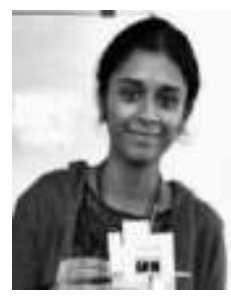

B.Arch., $4^{\text {th }}$ Year Student, enthusiastic in documentation, analysis and Research as a part of her interests along with the course curriculum in exploring the application of History in architectural Design and town planning. Mobile: 08463088927

meghanaidu2312@gmail.com

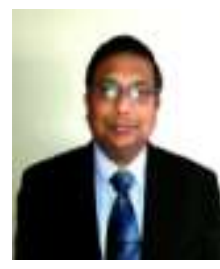

Pursued Master of Technology (Planning) at JNAFAU, Hyderabad. Research focuses on facts, findings and applications from History of Architecture, also in integrating Urban Design and Architectural elements through empirical solutions.

Ph No: +918008413476

rpdesigndesk@gmail.com 